International Journal of Child, Youth, and Family Studies (2014): 5(4.2) 741-750

\title{
RETHINKING PHOTOGRAPHY AS EVENT
}

\section{Kimberley Ainsworth}

\begin{abstract}
Within contemporary early childhood contexts, children's photography is often seen as a democratic practice that incorporates children's photographs as representations of children's inner experiences of thinking, feeling, and learning. This article outlines tensions arising from the author's photography inquiries, which took place within a Canadian preschool setting. Within the context of early childhood education (ECE) practice, anthropocentric, representational views of photography and child-centered practice are critiqued and contrasted with a relational materialist stance. The impacts of onto-epistemological positionings on ECE conceptions of knowledge and knowledge production, understandings of identities - of both children and Early Childhood Educators - and impacts on studio art practices are considered (Atkinson, 2011; Kind, 2013; Lenz Taguchi, 2011). Viewing early childhood photography as "event” and centering upon the materiality of photographs and camera, are presented as more ethical and authentic means of ECE art practice inquiry.
\end{abstract}

Keywords: early childhood education, photography, documentation, relational materialism, early childhood art

Kimberley Ainsworth is a graduate student in the School of Child and Youth Care, and Manager of Child Care Services, at the University of Victoria, P.O. Box 1700, STN CSC, Victoria, British Columbia, Canada, V8W 2 Y2.

E-mail: kainsw@uvic.ca 
International Journal of Child, Youth, and Family Studies (2014): 5(4.2) 741-750

What might it mean to consider the camera and photographs as bodies within the early childhood classroom? What might be set in motion as a result of centering upon the materiality of camera and photographs and decentering children? What might we notice if we shifted from a child-centered to a relational materialist paradigm - focusing our gaze upon the entanglements of children-camera-adults-photographs (E. Edwards, 2012; Kind, 2013; Lenz Taguchi, 2011). In this article, I draw upon my experiences as an early childhood educator to explore these questions. As a foundation for this inquiry, I reflect upon past tensions I have experienced in incorporating children's photography within my preschool program. Thinking of the camera and photographs as bodies requires us to move beyond contemporary anthropocentric positioning of early childhood pedagogy (Lenz Taguchi, 2011). Within the ECE classroom, the camera is often seen as a tool for documenting children's learning (Dahlberg, Moss, \& Pence, 2007; C. Edwards, 2012; Government of British Columbia, 2008). My intention is to explore other meanings for photography, viewing it as a studio inquiry. In shifting to a relational materialist paradigm, I will contemplate what is privileged as "knowledge" and "learning", and how identities of children, educators, classroom, camera, and photographs are shaped. In moving beyond human-centric thinking, I will propose a shift from child-centered pedagogy and consider the ethics of such a shift. Finally, I will explore how we might treat photography within the ECE classroom, as "event” (Atkinson, 2011; Richardson \& Walker, 2011). What might we learn in following the camera's movements? What might we learn of the camera's entanglements with children, teachers, rules, histories, space, time and other materials?

\section{Photography in the Classroom: Flows and Tensions}

Over the course of three years of ECE practice, the camera had a regular presence within my preschool classroom and served several purposes. In my own hands, I saw the camera, primarily, as an instrument for documenting the children's learning. This practice of photography, which is inspired by Reggio Emilia philosophy, is often seen as an essential aspect of reflexive ECE practice in the Euro-Western world (Carr, 2001; Government of British Columbia, 2008; MacDonald \& Sánchez, 2010; Rinaldi, 2012; Tarr, 2011). In keeping with this, I used the photographs and my subsequent reflections as a means through which I could "listen" more deeply to the "hundred languages of children” (Fyfe, 2012; Rinaldi, 2012). At other times, my photographs served as a means of archiving our experiences within the classroom, for the benefit of the children's family members. These photographs offered us an historical preservation of special classroom memories. To this end, I carefully selected photographs that revealed heartwarming and coherent vignettes to display on preschool walls and in the children's learning stories. In these ways my relationship with photography in the classroom flowed: The camera helped me to meet my purposes of building community within the early childhood setting and provoking learning through our (the children's, family members' and mine) critical reflections. 
International Journal of Child, Youth, and Family Studies (2014): 5(4.2) 741-750

However, I also experienced tensions through the children's engagements with photography. From time to time, I offered my camera to the children to take their own photographs. As with others in my field, I conceptualized children's photography as a democratic practice for giving children an alternative language of expression or "voice" (Clark, 2005; DeMarie \& Ethridge, 2006; Government of British Columbia, 2008; Harris \& Manatakis, 2013). I assumed that the photos would be mirrors of the children's experiences and values and give me insight into their lives in our preschool. In reality, I found the children's photographs intriguing, yet also puzzling. The photographs revealed many close-ups of shoes, faces, backs of heads, obscure snippets of our play materials and preschool space. It seemed to me that in the children's hands, the camera revealed only fleeting glimpses of the inner worlds of the children that I wished to capture. While the photographs offered up interesting perspectives of our space, our materials, each other, and how they valued these, the children's approach to photography did not align with my own. As well, the children's reflections upon the photographs lacked the engagement I wished.

In keeping with Reggio Emilia philosophy, I viewed my desired role as educator as “co-inquirer” with children. As Carolyn Edwards (2012) states, “The teacher's role centers on provoking occasions of discovery through a kind of alert, inspired listening and stimulation of dialogue, co-action, and co-construction of knowledge” (pp. 152-153). In contrast to these educator goals, I was struggling with my sense of disappointment in the children's engagements with the camera. I made a few futile attempts to redirect the children's photography experiences, for example, asking the children to imagine that they were taking photographs for visitors from outer space. I appealed to the children to take photographs that would explain to alien visitors who we were and what our preschool was about. During each "re-focusing" attempt, the children listened to my instructions respectfully then scurried off to continue their photography experiences where they had left off, with my instructions cast aside. These resistances felt anything but coconstructive in nature! I felt ineffective and was left contemplating my identity as educator.

My own purposeful intentions with the camera seemed at odds with the, ostensibly, spontaneous intentions of the children's. I sought to make sense of the children's relationship with the camera. I pondered why the children might neglect my precious camera and leave it lying about, seemingly forgotten. I questioned why the children would loop the camera casually over their wrists to wear as a fashion accessory rather than use as intended. I wondered why one child seemed only interested in playing with the settings on my camera rather than taking photographs. My own complex history with the camera was at odds with those of these children. The children's photographs, their engagement with the camera, and their subsequent reflections never quite met with my expectations. In this space of tension, I stumbled about pedagogically, looking for a means to align the children's intentions to mine.

In retrospect, the entanglements of children-camera-teacher-photographs-spacehistories-time were tugging at me with lessons I was not yet ready to consider. As long as my focus remained child-centered, the materiality of the camera and photographs escaped 
International Journal of Child, Youth, and Family Studies (2014): 5(4.2) 741-750

my gaze. Through my anthropocentric stance, I viewed the photograph images as holding purely representational value and offering single images of "truth". Yet, perhaps there were other ways of viewing photography in our preschool - as partial, subjective, and offering multiple possibilities? I needed to lean into the dissension to think more broadly about how knowledge - both the children's and my own - could evolve through our engagements with the camera. Shifting to thinking of the children's photography as studio inquiry rather than a channel into children's inner worlds opens up new possibilities. A relational materialist epistemological perspective offers inroads for me to explore alternative photography meanings and possibilities.

\section{Ruptures}

Dennis Atkinson (2011), a former secondary school art educator turned scholar, points out how theoretical positions offer us lenses through which we come to understand our worlds. Our conceptions of what counts as knowledge, how knowledge is produced, and how we view identities of educators and children, are all shaped and regulated through the onto-epistemological frameworks we hold. Atkinson (2011) states that experiences that do not fit within these existing frameworks create tensions that can serve as precious ruptures from which new perspectives can emerge. In the world of artist William Kentridge, working through a stuck, in-between moment is, "where the real work takes place” (Sollins \& Dowling, 2009). As Atkinson (2011) argues:

We need pedagogies that are open to the irreducible singularity of what happens, pedagogies that can be fed and nourished by the surprise of the unexpected. Such pedagogies would then be of the event, pedagogies against the state, within their respective contexts. (p. 19)

In his exploration of pedagogy in art education, Atkinson (2011) cautions us that when we define pedagogy as simply knowledge transfer from teacher to student, then learning becomes subordinated to teaching.

In reflecting upon my own classroom experiences, I wondered how my goals for the children's learning were shaped by my own definitions and expectations of knowledge and knowledge production. Had I expected the children to simply follow my lead? How often had I prodded the children to tell me how the photographs represented their inner worlds, rather than noticing what and how the children interacted with the camera and photographs? My own conceptions of what counted as children's knowledge in photography inquiry blinded me to what children-camera assemblages were trying to teach me. Centering upon the assemblages of children-camera-photographs offers interesting new spaces for me to reconsider my definitions of learning, teaching, and knowledge. What if I suspended my own definitions of camera and photography knowledge to engage in more authentic co-inquiry, with the children, allowing the camera to lead the way? What if I made space in my inquiry to consider the materiality of camera and photographs and the entanglements between photographer, subjects, teacher, children, camera, histories, rules, and motivations? In the following sections I will expand upon each of these rupture points. 
International Journal of Child, Youth, and Family Studies (2014): 5(4.2) 741-750

\section{Camera and Photography Meanings}

Photography meanings can be seen as being shaped historically, socially, culturally, and discursively. Sylvia Kind (2013), in writing about ECE studio inquiries using photography, states that historically, photographs have been viewed as presenting "the real, tangible, and objective world" (p. 2). As Kind points out, these meanings assume an agential photographer/viewer and passive subject - a human-centric approach. The "material turn" has brought new thinking to the studies of archeology, anthropology, and geography. Within the field of early childhood education, this post-human movement has changed how photographic images are interpreted (E. Edwards, 2012; Hultman \& Lenz Taguchi, 2010; Kind, 2013; Vestberg, 2008). Historical, anthropocentric views of photography are now critiqued as failing to capture the inter-relatedness - the layered and nuanced entanglements - of photographer, subjects, camera, and photographs.

In my own classroom photography experiences, I was caught up in the polarities of representation and product versus ambiguity and process; thinking separated from doing and feeling; and camera as instrument versus camera with agency. I made suggestions to the children that they take photographs of their favorite areas of our preschool spaces and felt disappointment when the children instead used the camera as a prop in their dramatic play. What if I considered how the materiality of the camera called the children to engage in such playful encounters? What new relationships and histories were formed between children and cameras as a result of this play? What else did the cameras call children to do? What if I printed the children's photographs and allowed the children to use these as they wished as part of a studio art inquiry? What might the children teach me about photography, as a result? My gaze excluded the multiple, complex, and rich in-between spaces that comprise the world of the camera and photography. My humanist-social constructionist gaze also assumed that there was an essential inner world of children waiting for the "skilled" teacher to access. This takenfor-granted gaze excluded the multiple entanglements of material, teacher, histories, time and space, and what these might teach me. Materials cannot be understood in isolation; they are always in relationship with one another. As McCoy (2012) states:

Matter is not a formless blob that is given shape by our imaginings of it. It is not inert substance waiting to be discovered and described. It acts; matter pushes back. Some encounters might just be collisions-random and chance, but when encounters are lasting and they cohere, they are not just collisions. Forces are produced. Momentum. Counterforces. (p. 764)

Paying attention to the flux and agency of the materials, human and non-human - how they collide and co-shape one another - opens up exciting new ways to view studio art practices. 
International Journal of Child, Youth, and Family Studies (2014): 5(4.2) 741-750

\section{Centering the Camera, Decentering the Child}

As I reflect upon my experiences in the ECE classroom, I can see how the identity of the camera and photographs were always present but silenced. Assumed to be passive, instrumental, and objective, I never considered the multiple identities and possibilities of these non-human subjects. Materials ask questions of us and we respond in particular ways in return (Ingold, 2007; Lenz Taguchi, 2011). My child-centered pedagogy limited the questions I was open to receive. Critical child developmental psychologist, Erica Burman (2008), has queried the ethics of a child-centered approach. Burman (2008) argues that while child-centeredness sounds emancipatory, the child-centered discourse regulates us by keeping our focus on the individual child and disregarding social, political, and cultural forces at play. Post-humanists argue that a child-centered view disregards the non-human materiality also actively participating in the life of an early childhood program (Kind, 2013; Lenz Taguchi, 2011). These non-human materials are performative, always in relationship with human and non-human matter (PaciniKetchabaw, personal communication, August 12, 2013). As an early childhood educator, I can widen my gaze by noticing the multitude of assemblages that surround me assemblages of children, adults, and non-human matter (Lenz Taguchi, 2011). In widening my gaze, I notice the identities of materials are never fixed or static, but always in process: "caught up in the currents of the lifeworld” (Ingold, 2007, p. 1). Non-human cameras and photographs interact in particular ways with bodies, hands, histories, space, and other materials.

Centering upon the materiality of the camera and decentering children does not mean excluding children from my inquiries. Rather, in centering upon the in-between spaces of child-camera/photographs, I learn more about children. Light is shone on the shadows of previously unconsidered entanglements of the children with materials. With a relational materialist lens, I reflect back upon the preschool photography experiences and see how the materiality of the camera, with its interesting buttons, called children to engage with it, to tinker with its settings, to play with its digital images. In children's hands, the camera called upon children to stretch themselves into new roles, not only as photographers but also artists and creators of new games. I see the delight that digital images of our classroom play materials held for the children. Caught in the power of the lens, these play materials were magnified, framed, distorted, and isolated from other visual contexts. I see the pull these images had for the children in creating games for one another of “Guess-What-This-Is?” and in reflecting back, I wish that I had welcomed these playful games into our classroom instead of resisting these important camera encounters. How might the relationships of children and camera have evolved if I had centered upon the materiality of the camera and photographs? What might have been set in motion in our classroom had I offered several cameras to the group, rather than a single camera? I wonder how the materiality of photographs might have engaged the children had I set up a provocation of the children's printed images, to do with what they pleased. Inviting the materiality of cameras and photographs into our space, as studio inquiry with the children, presents so many possibilities! Decentering the children and 
International Journal of Child, Youth, and Family Studies (2014): 5(4.2) 741-750

centering upon the camera or the photographs as bodies, calls for my authentic engagement in co-inquiry with the children, keeping myself open to the unexpected. I contend this is a most ethical ECE practice as it provides new ways of understanding children.

\section{Photography as Event}

Thinking of photography as “event” increases the complexity of art practice, and opens up many more possibilities for photography as a form of ECE studio inquiry. Richardson and Walker (2011) draw upon Gilles Deleuze's "philosophical concept of becoming” (p. 6) in defining "event” as, "a multiplicity of relationships in constant flux at the intersection of thought and action” (p. 9). An event is not a single art-making experience but rather a sustained exploration of the art-making process, involving many experiences. Thinking of event means thinking more deeply about the process of process. As Richardson and Walker (2011) explain, "in this sense, experience is not something that happens or has happened; it is something happening” (p. 11). Thinking of photography as "event" means moving beyond chronological definitions of time and noticing instead how time is affected through our photography relationships. Does time expand or contract or intensify through photography experiences? In paying close attention to the child-camera-photographs-teacher entanglements, I wonder what I might learn about the stories and rules that govern human and non-human relationships with one another? In my noticing the camera and photographs "becoming-with" human and non-human subjects, my notions of children and ECE might also be transformed. In attending to the ways that photograph materiality is expressed or suppressed, I must shift from instrumental views of the camera. Setting up photography as potential event means keeping open to keenly observing what camera-bodies set in motion in the classroom. It calls upon us to be attuned to the nuances of camera and photography materiality and playing up, or exaggerating the properties of the camera and photograph materiality in innovative and generative ways.

\section{Conclusion}

Pedagogies are never innocent. In ECE practice, they are performative transforming what we count as knowledge, how we teach and how we view children, teacher, families, and materials' identities (Pacini-Ketchabaw, personal communication, August 12, 2013). As an early childhood educator, my meaning making in pedagogical practices continues to evolve. Moving away from anthropocentric and logocentric approaches (Lenz Taguchi, 2011) means viewing cameras, photographs, time, spaces, and all manner of human and non-human materials as agential and active co-participants in ECE settings. While counterintuitive to my early childhood educator training, moving beyond child-centered practice and decentering the child widens my gaze so that I might learn more about children through their relationships with the camera and photographs. By centering the camera and photographs and seeing these as bodies within the classroom, I wonder what lines of flight might be possible? What might happen if I viewed the photography as event and paid attention to the camera and photographs' resistances and their constraints, and followed their flows and rhythms instead? I wonder 
International Journal of Child, Youth, and Family Studies (2014): 5(4.2) 741-750

what these observations and sensitivities might generate for my early childhood understanding of children and early childhood pedagogy. I continue to look for ways in which "art practice and research acts provoke one another" (Kind, personal communication, August 15, 2013) in my continuing search for more meaningful and ethical ways of being with the children in my ECE practice. 
International Journal of Child, Youth, and Family Studies (2014): 5(4.2) 741-750

\section{References}

Atkinson, D. (2011). Art equality and learning: Pedagogies against the state. Rotterdam, The Netherlands: Sense Publishers.

Burman, E. (2008). Deconstructing developmental psychology. East Sussex, UK: Routledge.

Carr. M. (2001). Assessment in early childhood settings: Learning stories. London: Sage Publications Ltd.

Clark, A. (2005). Listening to and involving young children: A review of research and practice. Early Child Development and Care, 175(6), 489-505. doi: 10.1080/03004430500131288

Dahlberg, G., Moss, P., \& Pence, A. (2007). Beyond quality in early childhood education and care: Languages of evaluation. Oxon, UK: Routledge.

DeMarie, D., \& Ethridge, E. (2006). Children’s images of preschool: The power of photography. Young Children, 61(1), 101-104.

Edwards, C. (2012). Teacher, learner, partner and guide: The role of the teacher. In C. Edwards, L. Gandini, \& G. Forman (Eds.), The hundred languages of children: The Reggio Emilia experience in transformation (pp.147-172). Santa Barbara, CA: Praeger.

Edwards, E. (2012). Objects of affect: Photography beyond the image. Annual Review of Anthropology, 41, 221-234. doi: 10.1146/annurev-anthro-092611 $-145708$

Fyfe, B. (2012). The relationship between documentation and assessment. In C. Edwards, L. Gandini, \& G. Forman (Eds.), The hundred languages of children: The Reggio Emilia experience in transformation (pp.273-291). Santa Barbara, CA: Praeger.

Government of British Columbia. (2008). Understanding the British Columbia early learning framework: From theory to practice. Victoria, BC: Ministry of Education, Ministry of Healthy Living and Sport, Ministry of Children and Family Development.

Harris, P., \& Manatakis, H. (2013). Young children's voices about their local communities. Australasian Journal of Early Childhood. 38(3), 68-76. 
International Journal of Child, Youth, and Family Studies (2014): 5(4.2) 741-750

Hultman, K., \& Lenz Taguchi, H. (2010). Challenging anthropocentric analysis of visual data: A relational materialist methodological approach to educational research. International Journal of Qualitative Studies in Education, 23(5), 525542. doi: 10.1080/09518398.2010.500628

Ingold, T. (2007). Materials against materiality. Archaeological Dialogues, 14(1), 1-16. doi: 10.1017/S1380203807002127

Kind, S. (2013). Lively entanglements: The doings, movements and enactments of photography. Global Studies of Childhood, 3(4), 427-441.doi:

dx.doi.org/10.2304/gsch.2013.4.27

Lenz Taguchi, H. (2011). Investigating learning, participation and becoming in early childhood practices with a relational materialist approach. Global Studies of Childhood, 1(1), 36-50. doi: dx.doi.org/10.2304/gsch.2011.1.1.36

MacDonald, M., \& Sánchez, A. (2010). Provoking dialogue: Promote a deeper understanding of teaching and learning through images and documents. Canadian Children, 35(2), 25-30.

McCoy, K. (2012). Toward a methodology of encounters: Opening to complexity in qualitative research. Qualitative Inquiry (9x8762-772. doi: $10.1177 / 1077800412453018$

Richardson, J., \& Walker, S. (2011). Processing process: The event of making art. Studies in Art Education, 53(1), 6-9.

Rinaldi, C. (2012). The pedagogy of listening: The listening perspective from Reggio Emilia. In C. Edwards, L. Gandini, \& G. Forman (Eds.), The hundred languages of children: The Reggio Emilia experience in transformation (pp.233-246). Santa Barbara, CA: Praeger.

Sollins, S., \& Dowling, S. (Creators). (2009, October 7). William Kentridge: Anything is possible. Compassion (Television series episode). In S. Sollins (Executive producer), ART21. New York: PBS. Retrieved from: http://www.pbs.org/art21/films/compassion

Tarr, P. (2011). Reflections and shadows: Ethical issues in pedagogical documentation. Canadian Children, 36(2), 11-16.

Vestberg, N. (2008). Archival quality: On photography, materiality and indexicality. Photographies, 1(1), 49-65. doi: 10.1080/17540760701786 